\title{
Assessment of Knowledge, Attitude and Practices (KAP) on Hantavirus Infections at Community Level in Mbeya Region, Tanzania
}

Lwitiho Sudi ${ }^{1,2^{*}}$, Willyhelmina Olomi ${ }^{1}$, Chacha Mangu ${ }^{1}$, Mokiti Tarimo ${ }^{2}$, Nyanda Ntinginya ${ }^{1}$, and Gabriel Shirima ${ }^{2}$

${ }^{1}$ NIMR-Mbeya Medical Research Center, P.O. BOX 2410, Mbeya, Tanzania

${ }^{2}$ Nelson Mandela African Institution of Science and Technology, Tanzania

"Corresponding author: Lwitiho Sudi, Nelson Mandela African Institution of Science and Technology, P.O.BOX 447, Arusha, Tanzania, Tel: +255755967883; E-mail: sudil@nm-aist.ac.tz

Received date: September 09, 2018; Accepted date: October 18, 2018; Published date: October 26, 2018

Copyright: @ 2018 Sudi L, et al. This is an open-access article distributed under the terms of the Creative Commons Attribution License; which permits unrestricted use; distribution; and reproduction in any medium; provided the original author and source are credited.

\section{Abstract}

Background: Hantaviruses are zoonotic RNA viral pathogens of public health concern in Tanzania and worldwide. These viruses circulate in both human and reservoir host in Tanzania, however, there is a gap in the assessment of knowledge, Attitude, and practices (KAP) which contributes to the transmission of the virus from Reservoir host to human being. This study aimed to assess the level of community knowledge, attitude, and practices that lead to the transmission of the virus from the reservoir host to a human being.
\end{abstract}

Methods: Cross-sectional questionnaire survey was conducted in the four districts of Mbeya region between June 2018 to July 2018, where questionnaire data were obtained from 438 participants. Descriptive statistics and Chi-square $\left(X^{2}\right)$ test were used to explain the response of the participants.

Results: (22/66) $33.3 \%$ and (22/372) $5.91 \%$ of both Health care workers and other members of the community, respectively had a knowledge about Hantavirus infections. (219/438) $50 \%$ of all participants have rodent breeding sites in their houses. However, (409/438) $93.4 \%$ of all participants did not wear masks when cleaning those breeding sites and this increases the risk for the transmission of Hantavirus infections.

Discussion: Low level of knowledge for Hantavirus infections observed in the community increases the uncertainty of patient management as well as endangers the community health due to an increase of practices which increases the chance of pathogen transmission to a human being from the reservoir host.

Conclusion: Updating the community about Hantavirus infection is more important as far as public health is concerned.

Keywords: Knowledge; Practices; Hantavirus; Public health

\section{Background}

Hantaviruses are single-stranded, enveloped, negative-sense RNA virus found in the family Bunyaviridae that cause two life-threatening human zoonoses namely, Hemorrhagic Fever with Renal Syndrome (HFRS) and Hantavirus Cardiopulmonary Syndrome (HCPS), with case fatality rates of up to $50 \%$ [1]. Diversity and distribution of Hantavirus serotypes and the seroprevalence distribution in East and Central Africa rise a public health concern about the Hantavirus within the region [2-7]. However, inadequate knowledge about Hantavirus infections in the society and the increase on the practices that favors the pathogen transmission from the reservoir hosts (rodents, shrews and bats) to human increases the risk for the transmission of hantavirus transmission to human and hence jeopardize the public health efforts.

Adequate knowledge on Hantavirus infections to Health Care Workers (HCWs) (i.e. clinical officers/medical doctors, nurses, diagnostic laboratory staff, etc.) and other members of the community plays an important role in the prevention and control of the virus transmission between reservoir host and human being. When the health care workers are well informed and updated about the viral infectious disease they assure a proper patient management as the patients arrive at health care facilities [8]. Different studies pointed out the Hantavirus serotypes circulation in Tanzania in both reservoir host [5] and human population [6] but there is a gap in the knowledge, attitude, and practices assessment on Hantavirus infections in the districts of Mbeya region which impacts the public health in terms of proper patient management and control of transmission.

Therefore, this study aimed to assess the knowledge and practices of Hantavirus infections among individuals with varying qualifications (i.e. HCWs and other occupations) living in the selected districts of the Mbeya region of Tanzania.

\section{Materials and Methods}

\section{Ethics and study participant}

The study was approved with the regional ethical regulatory body (MMREC) and the all participants involved in the study were provided with a free informed consent form to express their will to participate on the study. Participant with age equal and greater than 18 years old, 
Citation: Sudi L, OlomI W, Mangu C, Tarimo M, Ntinginya N, et al. (2018) Assessment of Knowledge, Attitude and Practices (KAP) on Hantavirus Infections at Community Level in Mbeya Region, Tanzania. J Trop Dis 7: 290. doi:10.4172/2329-891X.1000290

Page 2 of 4

sound minded with the ability and willing to respond on the questions were recruited on the study and administered a questionnaire.

\section{Study sites and data collection}

A cross-section interview-based survey among residents of four districts in Mbeya region, south-western of Tanzania (Kyela district, Mbarali district, Mbeya rural district and Mbeya municipal district) was conducted using a validated questionnaire. Study participants were provided with questions, which assess the knowledge on the Hantavirus infections and practices that lead them onto the risk of encountering the Hantaviruses from infected reservoir host.

\section{Statistical analyses}

Data were collected and entered in Microsoft Excel and imported to STATA software-version 14 for analysis, Descriptive statistics were used to represent the characteristics of the participant, numeric data were analyzed using measure of central tendency while Chi-square test $\left(\chi^{2}\right)$ was used to compare the respondents in the districts within Mbeya region who have knowledge of Hantavirus infections, transmission modes (Hantavirus cardiopulmonary syndrome or hemorrhagic fever with renal syndrome) and the relationship between febrile illness and Hantavirus. The level of significant was held at $95 \%$ confidence interval and less than 0.05 level of precision.

\section{Results}

\section{Characteristics of the participants}

The mean of age for all 438 participants involved in the study was 34.2 (SD 11.1) years and female to male ratio of 1.49:1. Only (63/438) $14.38 \%$ of all participants were of age group greater than 45 years old. (86/438) $19.83 \%$ and (119/438) $27.17 \%$ of participants have achieved a secondary and college level of education respectively. (66/438) $15.07 \%$ of all participants were health care workers while the rest were the members of the community with diverse of occupations including lawyers, teachers, entrepreneurs, agriculturalists, engineers etc. (240/438) $54.8 \%$ of all participants have estimated net income per month below 250,000Tsh while (85/438) $19.41 \%$ of all participant declined to respond on their income per months (Table 1) due to unspecified reasons.

\begin{tabular}{|c|c|}
\hline \multicolumn{2}{|l|}{ Age group } \\
\hline $18-25$ yrs & $98(22.37 \%)$ \\
\hline $26-45$ yrs & $277(63.24 \%)$ \\
\hline$>45$ yrs & $63(14.38 \%)$ \\
\hline \multicolumn{2}{|l|}{ Sex } \\
\hline Female & $262(59.82 \%)$ \\
\hline Male & $176(40.18 \%)$ \\
\hline \multicolumn{2}{|l|}{ Education } \\
\hline No formal education & $26(5.94 \%)$ \\
\hline Primary level & $207(47.26 \%)$ \\
\hline Secondary level & $86(19.83 \%)$ \\
\hline College/University & $119(27.17 \%)$ \\
\hline
\end{tabular}

\begin{tabular}{|l|l|}
\hline Occupation & $149(34 \%)$ \\
\hline Enterpreneurs & $165(37.67 \%)$ \\
\hline Farmers & $58(13.24 \%)$ \\
\hline Other occupations (e.g. lawyers, architects', accountants etc.) & $23(5.25 \%)$ \\
\hline Medical doctors & $26(5.94 \%)$ \\
\hline Nurses & $17(3.88 \%)$ \\
\hline Medical Laboratory personnel & \\
\hline Income generation per months (Tshs) & $127(29.00 \%)$ \\
\hline$<100,000$ & $113(25.8 \%)$ \\
\hline $100000-250000$ & $92(21.00 \%)$ \\
\hline $250000-1000000$ & $21(4.79 \%)$ \\
\hline$>1000000$ & $85(19.41 \%)$ \\
\hline Decline to give the answers & \multicolumn{2}{|l|}{} \\
\hline Districts involved in the interview & $151(34.47 \%)$ \\
\hline Kyela & $96(21.96 \%)$ \\
\hline Mbarali & $98(22.37 \%)$ \\
\hline Mbeya municipal & $93(21.23 \%)$ \\
\hline Mbeya rural & \\
\hline
\end{tabular}

Table 1: Showing the characteristics of the participants $(n=438)$.

\section{Assessment of knowledge on the Hantavirus infections}

Only (22/66) 33.3\% of the Health care workers (HCWs) participants responded correctly that rodents, bats, and shrews are the reservoir host for Hantavirus and only (22/372) 5.91\% of other members from the community which are non-health care workers (non-HCWs) know that rodents, shrews, and bats are the reservoir hosts for Hantavirus and on the assessment of whether the responders know if Hantavirus can cause febrile illness, only (34/66) 51.52\% and (57/372) $15.32 \%$ of both HCWs and other occupations respectively knows that Hantavirus can cause febrile illness (Table 2). With regard of transmission modes of Hantavirus only (40/66) $60.61 \%$ of HCWs and (84/372) $22.58 \%$ of other members from the community respond correctly that Hantavirus can be transmitted from infected reservoir host such as rodents through inhalation of contaminated aerosols with viral pathogens or being bitten with infected rodents or eating the fruit /food which has been eaten with infected rodents.

\begin{tabular}{|l|l|l|l|}
\hline & $\begin{array}{l}\text { Healthcare } \\
\text { Workers } \\
\text { (HCWs) }\end{array}$ & $\begin{array}{l}\text { Other } \\
\text { occupatio } \\
\text { ns }\end{array}$ & $\begin{array}{l}\text { P value } \\
\text { Cl:95\% }\end{array}$ \\
\hline $\begin{array}{l}\text { Participants wh responded } \\
\text { correctly about the reservoir host } \\
\text { and the viral pathogen causing } \\
\text { Hantavirus infection. }\end{array}$ & 22/66 (33.33\%) & $\begin{array}{l}22 / 372 \\
(5.91 \%)\end{array}$ & $\begin{array}{l}\mathrm{p}<0.000 \\
1\end{array}$ \\
\hline $\begin{array}{l}\text { A participant who responded } \\
\text { correctly about the modes of } \\
\text { transmission for Hantavirus } \\
\text { infection. }\end{array}$ & $40 / 66(60.61 \%)$ & $\begin{array}{l}84 / 372 \\
(22.58 \%)\end{array}$ & $\begin{array}{l}\text { p<0.000 } \\
1\end{array}$ \\
\hline
\end{tabular}




\begin{tabular}{|l|l|l|l|}
\hline A participant who knows that & & $57 / 372$ & p<0.000 \\
Hantavirus can cause febrile illness. & 34/66(51.52\%) & $(15.52 \%)$ & 1 \\
\hline
\end{tabular}

Table 2: Showing the proportions of participants with knowledge about Hantavirus infections.

Only (48/151) $31.79 \%$ of the participant from Kyela district knows that the patients infected Hantavirus may progress to Hantavirus cardiopulmonary syndrome or Hemorrhagic fever with renal syndrome while in Mbeya rural and Mbarali districts the understanding about clinical manifestation of hantavirus disease was below 10\% (Figure 1).

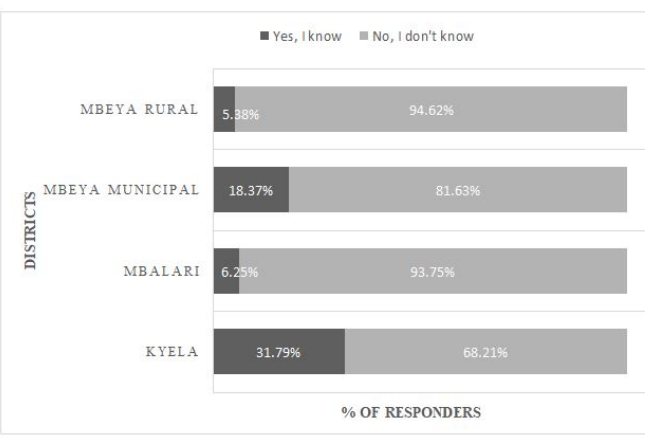

Figure 1: Response to the question of whether people may get HCPS/HFRS after being infected with Hantavirus.

\section{Assessment of attitudes which may contribute to the transmission of Hantavirus infections from the reservoir host to human being}

(97/438) $22.15 \%$ of community members have the tendency of eating food or fruits which has been eaten by reservoir host for Hantavirus such as rodents or bats and this endangers the community health in terms of emerging infectious diseases. (23/438) 5.25\% of individuals living in both districts have the tendency of collecting organic manure from bats colonies without wearing a mask and this increases the risk of transmission of emerging infectious diseases (Figure 2).

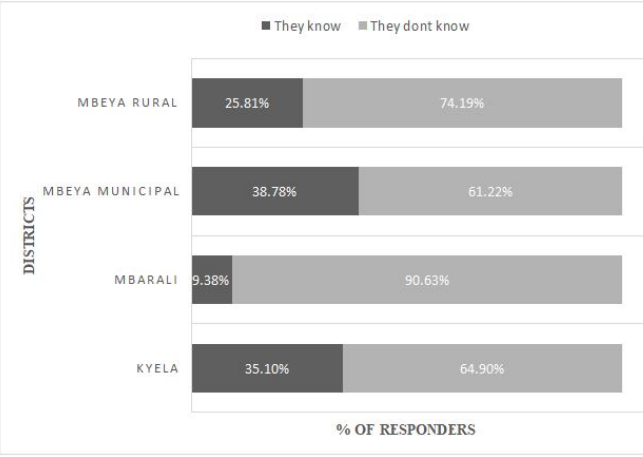

Figure 2: Response to the modes of transmission of Hantavirus within districts of Mbeya region.

\section{Assessment of the practices which may expose the human onto the contact with Hantavirus infections}

About (218/438) 49.5\% of the residence of Mbeya region participated in the questionnaire interview had rodent breeding sites in their houses, however only (14/218) $6.6 \%$ of the participants they wear mask and gloves during cleaning of those sites and this increases the risk of Hantavirus transmission. Not only (184/438) $42.0 \%$ of individuals recruited in the study uses food or fruits which has already been eaten by rodents or bats but also (255/438) 58.2\% those individuals are involved in agricultural plantations i.e. Banana plantations, cocoa, and palm trees which play part as the roosting sites and favor the population growths of bats as the reservoir hosts for Hantavirus. Only (35/438) $8.0 \%$ of individuals are involved in the forest activities such as Timbering and charcoal making which expose them onto risk of encountering infected reservoir hosts.

\section{Discussion}

Public health knowledge within the community with regards of emerging infectious diseases is so crucial as the community remains alert in terms of the infectious pathogen and hence the implementation of particular emerging infectious disease prevention and control strategies which results into better community health [9-11].

Hantavirus infections affects more individuals with low income [12-14] and also living in rural and semi-urban areas [9,15-17] due to exposed risks factors such as type of economic activities they are being involved, presence of rodent breeding sites in their houses and presence of low ventilation in their houses which cause them to inhale the contaminated dust with Hantavirus during a process cleaning their houses. This study shows that, about $50 \%$ of the individuals living in both districts (i.e. Kyela, Mbarali, Mbeya municipal and Mbeya rural) within Mbeya region have rodent breeding sites in their houses while $93.4 \%$ of these community members don't use mask or gloves during cleaning those breeding sites and this increases the danger of being infected.

About $54.8 \%$ of the individuals involved in the study have the monthly income of less the 250,000Tsh per month as the net income while $19.4 \%$ rejected to give out the data about their net income per month due to uncertain reasons. Due to a higher number of individual with low income living in both districts, many individuals are involved in activities such as timbering, forest agricultural activities which expose them to the reservoir host such as shrews which harbors Hantavirus pathogens $[18,19]$.

Higher knowledge or awareness about Hantavirus pathogen and diseases has been associated with a decrease in the burden of emerging diseases such as Hantavirus infection in Europe [20] due to the avoidance of practices which lead to the exposure and transmission or spread or outbreak of the respective diseases and this assures the proper health of the population. Low level of knowledge on the both HCWs and community members as observed in both districts within this study about Hantavirus pathogen, Hantavirus infections and the risk factors for the transmission of the virus to human being, while there is Hantavirus pathogen circulation in the reservoir host and community (NIMR MMRC 2017, Unpublished results) and also there is an existence of practices in the population which might lead to the transmission of the pathogen from the infected reservoir host to human population, not only increases the chance of human infections 
Citation: Sudi L, OlomI W, Mangu C, Tarimo M, Ntinginya N, et al. (2018) Assessment of Knowledge, Attitude and Practices (KAP) on Hantavirus Infections at Community Level in Mbeya Region, Tanzania. J Trop Dis 7: 290. doi:10.4172/2329-891X.1000290

Page 4 of 4

but also highlight the mismanagement of patients with Hantavirus infections wherever he/she arrive at the health care facility.

Therefore, it is necessary to rise the community knowledge and awareness about Hantavirus infections in both clinical and nonclinical society as the preventive and control strategy, since it would help to keep the society well informed about the infections as well as enabling the implementation of the preventive and control strategy on the community.

\section{Conclusion}

Updating the society about the Hantavirus infections in both Heath care workers and other members of the community located in both districts within rural and urban setting will not only ensure the proper management of the febrile patients when arrives at the health care centres but also helps the individuals to prevent themselves from being infected with Hantavirus and hence limits the transmission of the infections.

\section{Authors Contribution}

SL, GS, and NN designed and conceived the study, CM and SL involved in the data collections, OW and SL analyzed the data, SL designed the first draft and finalized the manuscript. All authors contribute to the comments and approved the final draft.

\section{Conflicts of Interest}

There is no conflict of interest between authors.

\section{Acknowledgment}

This work was supported by NIMR MMRC who provide the grant which enables the accomplishment of the work and the Nelson Mandela African Institution of science and technology for the guidance of research work. The study got an approval from Mbeya Medical Research Ethical Committee (MMREC). We give thanks Mbeya region and districts authorities who provide the permits for conducting the study and our sincere thanks to all participants who provide the questionnaire data and hence the success of the study.

\section{References}

1. Kruger DH, Figueiredo LTM, Song J-W, Klempa B (2015) Hantavirusesglobally emerging pathogens. J Clin Virol 64: 128-136.

2. Těšíková J, Bryjová A, Bryja J, Lavrenchenko LA, Goüy de Bellocq J (2017) Hantavirus Strains in East Africa Related to Western African Hantaviruses. Vector-Borne Zoono Dis 17: 278-280.

3. Chau R, Bhatt N, Manhiça I, Cândido S, de Deus N, et al. (2017) First serological evidence of hantavirus among febrile patients in Mozambique. Int J Infect Dis 61: 51-55.

4. Sudi L, Mangu C, Tarimo T, Ntinginya N, Shirima G (2018) Hantaviruses in East and Central Africa. Am Res Commun 6: 1-14.

5. Kang HJ, Stanley WT, Esselstyn JA, Gu SH, Yanagihara R (2014) Expanded host diversity and geographic distribution of hantaviruses in sub-Saharan Africa. J Virol 88: 7663-7667.

6. Hofinger DM, Nofchissey R, Jacobson M, Goade D (2006) 443 serological survey of hantavirus in adult humans living in tanzania. J Invest Medi 54: S156.1-S156.
7. Klempa B, Fichet-Calvet E, Lecompte E, Auste B, Aniskin V, et al. (2006) Hantavirus in African wood mouse, Guinea. Emerging Infect Dis 12 838-840.

8. Bryant $\mathrm{T}$ (2002) Role of knowledge in public health and health promotion policy change. Health Promotion Int 17: 89-98.

9. Morse SS (1996) Emerging viruses: Oxford University Press on Demand.

10. Brownstein JS, Freifeld CC, Reis BY, Mandl KD (2008) Surveillance Sans Frontieres: Internet-based emerging infectious disease intelligence and the Health Map project. PLoS Medicine 5: e151.

11. Walsh K (2018) E-learning modules in new and emerging infectious diseases improve the applied knowledge and problem-solving skills of healthcare professional learners. BMJ Simulation and Technology Enhanced Learning.

12. Krüger DH, Schönrich G, Klempa B (2011) Human pathogenic hantaviruses and prevention of infection. Hum vaccines 7: 685-693.

13. Ettinger J, Hofmann J, Enders M, Tewald F, Oehme RM, et al. (2012) Multiple synchronous outbreaks of Puumala virus, Germany, 2010 Emerging Infect Dis 18: 1461.

14. Krüger DH, Ulrich RG, Hofmann J (2013) Hantaviruses as zoonotic pathogens in Germany. German Med J Int 110: 461.

15. Vaheri A, Henttonen H, Voutilainen L, Mustonen J, Sironen T, et al (2013) Hantavirus infections in Europe and their impact on public health. Rev Med Virol 23: 35-49.

16. Watson DC, Sargianou M, Papa A, Chra P, Starakis I, et al. (2014) Epidemiology of Hantavirus infections in humans: A comprehensive, global overview. Critical Rev Microbiol 40 :261-72.

17. de Oliveira RC, Guterres A, Fernandes J, D'Andrea PS, Bonvicino CR, et al. (2014) Hantavirus reservoirs: current status with an emphasis on data from Brazil. Viruses 6: 1929-1973.

18. Panos G, Sargianou M, Papa A, Gogos C (2014) Hantaviruses: seroprevalence and risk factors among humans in Achaia prefecture, Greece. BMC Infect Dis14: P91.

19. Sin MA, Stark K, Van Treeck U, Dieckmann H, Uphoff H, et al. (2007) Risk factors for hantavirus infection in Germany, 2005. Emerg Infect Dis 13: 1364 .

20. Suzuki K, Mutinelli LE (2009) Knowledge and practices about hantavirus pulmonary syndrome in a cluster of Japanese communities in Argentina. Am J Public Health 25: 128-133. 